\title{
Prevalence and intensity of black-spot disease in fish community from a subtropical stream (Santa Lucía river basin, Uruguay)
}

\author{
Franco Teixeira-de Mello ${ }^{* 1,2}$ and Gabriela Eguren ${ }^{1}$ \\ ${ }^{1}$ Grupo de Investigación en Ecotoxicología y Química Ambiental, Facultad de Ciencias, Iguá 4225. CP. 11400, \\ Universidad de la República, Montevideo, Uruguay. \\ ${ }^{2}$ Grupo de Investigación en Ecología Básica y Aplicada, Asociación Civil I+D, Iguá 4225, CP 11400, Montevi- \\ deo, Uruguay.
}

* Corresponding author: frantei@fcien.edu.uy

Received: 26/11/06

Accepted: 2/6/08

\begin{abstract}
Prevalence and intensity of black-spot disease in a fish community from a subtropical stream (Santa Lucía river basin, Uruguay)

The objective of the present study was to identify fish species susceptible to black spot disease, the temporal variation in intensity prevalence and abundance of black spot, and its correlation with environmental and host parameters. In order to do so, several sampling campaigns were conducted bimonthly during one year, along the main course of an agricultural watershed. A total of twenty-seven fish species were collected, out of which only two, Astyanax aff. fasciatus ("mojarra") and Oligosarcus jenynsii ("dientudo") presented black spot disease. In A. aff. fasciatus, $63 \%$ of black spot prevalence was registered and did not show significant seasonal changes during the sampling period, nor did the abundance and intensity. Regarding possible relations between the disease and environmental and host parameters, a higher intensity of black spot infection was observed in the ventral region of the fish and allometric coefficient $\left(W_{T}-L_{S}\right.$, relationship) values did not differ significantly between parasitized and non-parasitized fish groups.
\end{abstract}

Key words: Black-spot, metacercariae digeneans, Astyanax aff. fasciatus, subtropical stream, Santa Lucía river basin.

\section{RESUMEN}

Prevalencia e intensidad de la enfermedad del punto negro en la comunidad de peces en un arroyo subtropical (cuenca del río Santa Lucía, Uruguay)

El objetivo del presente estudio fue identificar las especies susceptibles a la enfermedad del punto negro, la variación temporal de su intensidad, prevalencia y abundancia; así como su relación con parámetros ambientales y del hospedador. Para ello, se realizaron muestreos bimensualmente durante un año, en el curso principal de una cuenca agrícola suburbana. Fueron colectadas un total de veintisiete especies, de las cuales en solo dos, Astyanax aff. fasciatus ("mojarra") y Oligosarcus jenynsii ("dientudo"), se observó la enfermedad del punto negro. En A. aff. fasciatus se registró una prevalencia de puntos negros del $63 \%$ y la misma no presentó diferencias significativas durante el período de muestreo, al igual que su abundancia e intensidad. En cuanto a las posibles relaciones de la enfermedad con parámetros ambientales y del hospedador, se observó una mayor intensidad de la infección en la región ventral de los peces y no se encontraron diferencias significativas en los valores del coeficiente alométrico (relación $\mathrm{W}_{\mathrm{T}}-\mathrm{L}_{\mathrm{S}}$ ) entre los peces parasitados y no parasitados.

Palabras clave: Punto negro, metacercarias digenea, Astyanax aff. fasciatus, arroyo subtropical, cuenca del río Santa Lucía. 


\section{INTRODUCTION}

The black-spot disease, caused by encystment of metacercariae of digenic trematodes, produces a response easily recognizable in the fish for the accumulation of melanin around the encysted metacercariae.

The life cycle of these parasites includes two intermediate hosts, the first stage (miriacida) infects snails, and the second intermediaries are fishes. When the cercariae stage comes out from the snails, it massively attacks the fish, entering through the skin, muscles and fins of the fishes remaining there in the metacercariae stage until the infested host is eaten by other fish or waterfowl. In the digestive tract of the final host, the adult flukes reproduce. The eggs are released via excreta and pass to the water where the miraciadia emerges, penetrates the snails and starts a new cycle (Olsen, 1974; de Kinkelin et al., 1985). Freshwater digenean's life cycle is affected by temperature, seasonal changes in prevalence and abundance related to enhance cercarial emergence with an increase in water temperature are reported (Chubb, 1979). To our knowledge, there are no studies in Uruguay about the black-spot disease of freshwater fish; for this reason the prin- cipal trematodes and its specificity in terms of intermediate hosts (snails and fishes) are unknown.

Several digenic trematode species have been reported as pathogenic for secondary intermediary fish hosts. The infection may be lethal, especially during the first months of the fish life cycle (Lucký, 1970). Both in aquaculture and natural populations, most parasite-fish host systems present negative or neutral impacts of parasites on the host fish survival, growth and condition (Lyayman and Sadkovskaya, 1952; Harrison and Hadley, 1982; Baker and Bulow, 1985; Sindermann, 1987). However, an increased growth of parasitized fish have been informed in several studies, especially related to cestodes parasites (Arnott et al. 2000; Museth, 2001; Loot et al., 2002). In digenean larvae infected fishes, increased growth has only been recorded in the Cyprinidae Phoxinus phoxinus (Linnaeus, 1758), with this effect disappearing in high infections (Ballabeni, 1994).

These parasites can promote different effects in different fish species with consequences at the population level. In this sense, the aim of the present study was to identify fish species susceptible to black spot disease, its temporal variation regarding intensity, prevalence, abun-

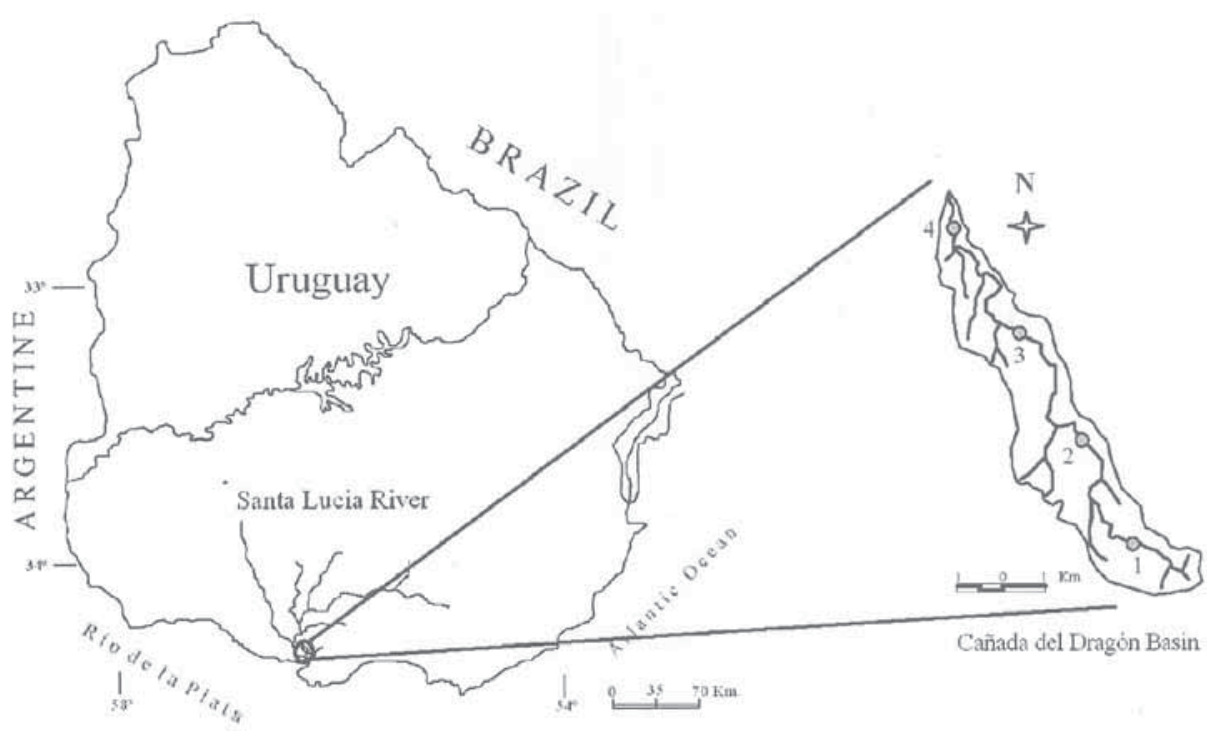

Figure 1. Map of the study area, showed the four sampling sites of Cañada del Dragón stream, Santa Lucía river basin. Mapa del área de estudio, se muestran los cuatros sitios de muestreo en el Arroyo Cañada del Dragón, Cuenca del río Santa Lucía. 
dance, and its correlation with environmental and host parameters.

\section{MATERIAL AND METHODS}

The study was carried out in an agricultural watershed located in the lower-basin of Santa Lucía River (Fig. 1), the most important water resource for human consumption in Uruguay (DNH, 1999). The watershed, Cañada del Dragón $\left(34^{\circ} 47^{\prime} 07^{\prime \prime} \mathrm{S}, 56^{\circ} 14^{\prime} 56^{\prime \prime} \mathrm{W}\right.$ to $\left.34^{\circ} 42^{\prime} 15^{\prime \prime} \mathrm{S}, 56^{\circ} 18^{\prime} 34^{\prime \prime} \mathrm{W}\right)$, covers $14.7 \mathrm{~km}^{2}$ and approximately $50 \%$ is covered by deciduous fruit-tree plantations. The main course is $13.7 \mathrm{~km}$ long, and according to Strahler (1986) criteria, was classified as a third order stream.

Six sampling campaigns were conducted from July 2002 to June 2003, in four sites along the stream to ensure a high number of environments (riffles and pools, vegetated and non-vegetated zones), in order to capture a representative number of the species presented in the Cañada del Dragón stream. Fish were captured using electro fishing (Sachs Elektrofischfanggerate $\mathrm{GmbH}$, Type FEG 1000), and the sampling effort in each site was 15 electric pulses along 100 meters. All fish were classified taxonomically and only the individuals that presented black spot disease were transported to the laboratory. These fish were sacrificed with an overdose of anesthesia (solution of 2-Phenoxy-ethanol, $1 \mathrm{ml} \mathrm{L}^{-1}$ ), fixed in formalin $(10 \%)$, preserved in alcohol $(70 \%)$, and stored at the Vertebrate Collection of Facultad de Ciencias, Universidad de la República (Uruguay) (Institutional code ZVC-P). Samples of fish skin with black spot disease were wholly mounted and the metacercariae, stored in the Helminthological Collection from the above mentioned Facultad de Ciencias.

Water parameters such as $\mathrm{pH}$, dissolved oxygen concentration $\left(\mathrm{mg} \mathrm{L}^{-1}\right)$, conductivity $\left(\mu \mathrm{S} \mathrm{cm}^{-1}\right)$ and temperature $\left({ }^{\circ} \mathrm{C}\right)$ were measured in situ. Water samples were collected and analyzed for alkalinity $\left(\mathrm{mg} \mathrm{CaCo}_{3} \mathrm{~L}^{-1}\right)$, organic matter and total suspended solids ( $\mathrm{mg} \mathrm{L}^{-1}$ ) (APHA, 1995). The temporal variation of water physicochemical parameters was analyzed using the nonparametric Kruskal-Wallis test (Zar, 1999).

In the species that presented black spot disease, prevalence (percentage of fish with black spot disease), mean abundance (mean number of black spots considering all fish examined) and mean intensity (mean number of black spots per fish infected) were calculated following Bush et al., (1997). Temporal variation of prevalence was tested using Proportion tests, whereas changes in abundance and intensity were tested using the non-parametric Kruskal-Wallis test (Zar, 1999).

The relationship between the number of parasites and environment (water physico-chemistry parameters) and host parameters (fish total, standard length, and weight) were evaluated through the non-parametric Spearman correlation test (Sokal and Rohlf, 1979). To determine infection preference, each organism was subdivided in four

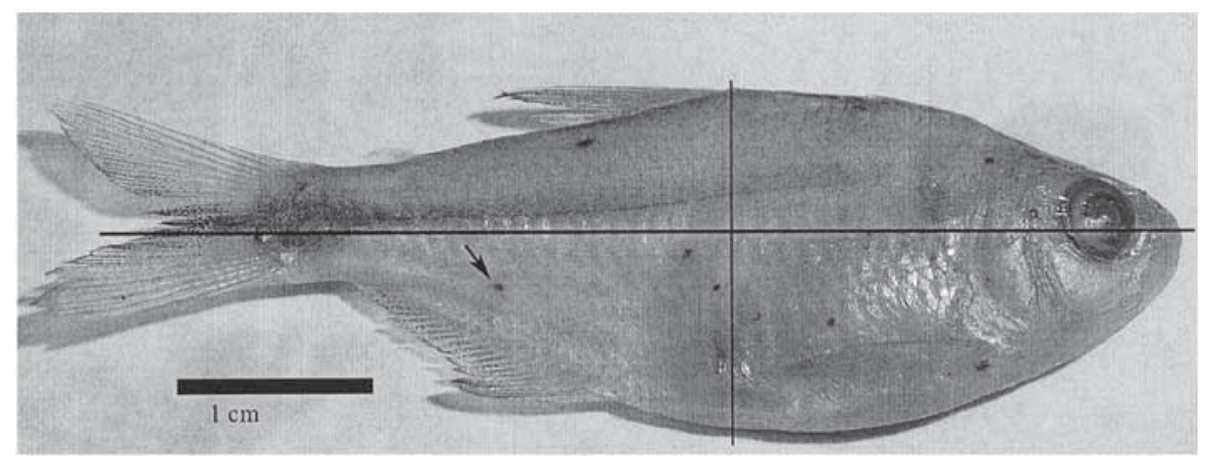

Figure 2. Astyanax aff. fasciatus, picture showing the four regions of the body employed for the black-spot analysis. Arrow indicates the black spot. Astyanax aff. fasciatus, fotografía mostrando las cuatro regiones del cuerpo empleadas para el análisis de los puntos negros. La flecha indica un punto negro. 
anatomical regions (Fig. 2) and the number of black spots in each section was compared using Wilcoxon matched-paired test (Zar, 1999).

We compared the growth type of parasitized and non-parasitized fish ( $n=107$ and 57, respectively, for $A$. aff. fasciatus) estimating the parameters of the potential relationship $W_{T}=a S_{L}^{b}$, where $W_{T}$ is total weight and $S_{L}$ is standard length (Ricker, 1973), by a linear regression after data logarithmic transformation. We tested whether fish growth was statistically different between groups, by t-tests with $\alpha=0.05$ (Mayrat, 1970; Ricker, 1973; Ricker, 1975).

\section{RESULTS}

A total of 2235 fish were collected, corresponding to 27 species and five Orders. Only two species, of the Characidae family, presented black spot disease: Astyanax aff. fasciatus (Cuvier, 1819) ("mojarra") $(n=164)$ and Oligosarcus jenynsii (Günther, 1864) ("dientudo") $(n=2)$. One hundred and five individuals of A. aff. fasciatus (prevalence $=63 \%$, mean intensity $=7$ ) and both individuals of $O$. jenynsii presented black spot disease. Therefore, the temporal variation and its correlation with environmental and host's parameters were analyzed only for A. aff. fasciatus.

The results for prevalence, mean abundance, and intensity of black spot disease in A. aff. fasciatus, is shown in Table 1. The Kruskal-Wallis test did not show significant differences for abundance temporal variations $\left(H_{5,150}=6.85 ; p=0.23\right)$
Table 1. Summary statistics of black spot disease in Astyanax aff. fasciatus (prevalence, abundance and intensity) from Cañada del Dragón stream, SD, standard deviation, $n$, number of individuals captured. Resumen estadístico de la enfermedad del punto negro en Astyanax aff. fasciatus (prevalencia, abundancia e intensidad) del arroyo Cañada del Dragón, SD, desvio estándar, n, número de individuos capturados.

\begin{tabular}{lccccc}
\hline Sampling & $\begin{array}{c}\text { Prevalence } \\
\% \text { infected } \\
\text { fish }(n)\end{array}$ & $\begin{array}{c}\text { Abundance } \\
\text { Mean } \\
\pm \text { SD }\end{array}$ & Range & $\begin{array}{c}\text { Intensity } \\
\text { Mean } \\
\pm \text { SD }\end{array}$ & Range \\
\hline July & $66.6(9)$ & $6.1 \pm 8.4$ & $0-23$ & $9.8 \pm 8.9$ & $1-23$ \\
September & $66.6(18)$ & $1.8 \pm 2.7$ & $0-8$ & $2.8 \pm 2.2$ & $1-8$ \\
November & $63.1(65)$ & $3.6 \pm 6.7$ & $0-33$ & $5.8 \pm 7.7$ & $1-33$ \\
February & $60.4(48)$ & $3.9 \pm 8.3$ & $0-52$ & $6.6 \pm 9.8$ & $1-52$ \\
April & $77.8(18)$ & $10.5 \pm 14.7$ & $0-51$ & $13.7 \pm 15.5$ & $1-51$ \\
June & $83.3(6)$ & $7.3 \pm 8.1$ & $0-21$ & $8.8 \pm 8.1$ & $1-21$ \\
\hline
\end{tabular}

and intensity $\left(H_{5,104}=9.36 ; p=0.10\right)$. The Proportion test did not show significant differences for prevalence's temporal variation $(p>0.05)$.

The physico-chemical parameters analyzed (Tables 2 and 3) showed a significant temporal variation (Kruskal Wallis test, $p<0.05$ ), but did not show a significant correlation with black spot intensity (Spearman $r, p<0.05$ ).

We found no significant correlation between intensity of the disease and host's parameters (standard and total length, and weight). However, we found significant differences in the intensity of black spot between sections of the fish, particularly ventral $($ median $=2)$ and dorsal region $($ median $=1)$ (Wilcoxon test, $t=1561.5, p<0.05$ ).

The regressions for the two fish groups (parasitized and non-parasitized) were:

1) Parasitized fishes:

$\log W_{T}=\log -1.44( \pm 0.03)+2.85( \pm 0.04) \log S_{L}$

Table 2. Summary of the mean $\mathrm{pH}$, conductivity $\left(\mathrm{C} \mu \mathrm{S} \mathrm{cm}{ }^{-1}\right)$, temperature $\left({ }^{\circ} \mathrm{C}\right)$, and dissolved oxygen $\left(\mathrm{DO} \mathrm{mg} \mathrm{l^{-1 }}\right)$. SD $=\operatorname{standard}$ deviation (mean and SD values based on 10 replicate collected from 4 sities, total $n=40$ ), from Cañada del Dragón stream. Resumen de los valores medios para el $\mathrm{pH}$, conductividad $\left(C \mu \mathrm{cm}^{-1}\right)$, temperatura $\left.{ }^{\circ} \mathrm{C}\right)$, y oxígeno disuelto $\left(\mathrm{DO} \mathrm{mg}^{-1}\right)$. SD $=$ desvío estándar (valores de la media y SD basados en 10 replicas colectadas en 4 sitios, total $\mathrm{n}=40$ ), en el arroyo Cañada del Dragón.

\begin{tabular}{|c|c|c|c|c|c|c|c|c|c|}
\hline \multirow[t]{2}{*}{ Sampling Date } & \multirow[t]{2}{*}{$n$} & \multicolumn{2}{|c|}{$\mathrm{pH}$} & \multicolumn{2}{|c|}{$\mathrm{C} \mu \mathrm{S} \mathrm{cm}-1$} & \multicolumn{2}{|c|}{$\mathrm{T}^{\circ} \mathrm{C}$} & \multicolumn{2}{|c|}{ DO $\mathrm{mg} \mathrm{l}^{-1}$} \\
\hline & & mean & SD & mean & SD & mean & SD & mean & $\mathrm{SD}$ \\
\hline July & 40 & 8.0 & 0.3 & 692.1 & 150.4 & 11.0 & 1.0 & 6.8 & 0.7 \\
\hline September & 40 & 7.6 & 0.2 & 593.0 & 79.5 & 16.6 & 1.1 & 6.1 & 0.4 \\
\hline November & 40 & 7.7 & 0.2 & 706.9 & 144.8 & 20.6 & 0.9 & 4.8 & 0.6 \\
\hline February & 40 & 7.3 & 0.3 & 457.2 & 77.7 & 24.4 & 0.6 & 4.0 & 0.5 \\
\hline April & 40 & 7.6 & 0.4 & 465.1 & 92.8 & 18.3 & 0.7 & 7.7 & 0.9 \\
\hline June & 40 & 7.5 & 0.3 & 423.2 & 147.8 & 10.9 & 0.4 & 8.9 & 0.8 \\
\hline
\end{tabular}


Table 3. Summary of the mean alkalinity (Alk, $\mathrm{mg} \mathrm{CaCo}_{3} \mathrm{l}^{-1}$ ), suspended total solids (STS, $\mathrm{mg}^{-1}$ ), and suspended organic matter ( $\mathrm{SOM}, \mathrm{mg} \mathrm{l}^{-1}$ ). SD = standard deviation (mean and SD values based on 3 replicate samples collected from 4 sities, total $n=12$ ), from Cañada del Dragón stream. Resumen de los valores medios para la alcalinidad (Alk, $\mathrm{mg} \mathrm{CaCo}_{3} \mathrm{l}^{-1}$ ), solidos totales en suspensión $\left(S T S, \mathrm{mg} \mathrm{l}^{-1}\right)$, y materia orgánica en suspensión $\left(S O M, \mathrm{mg} \mathrm{l}^{-1}\right)$. SD = desvío estándar (valores de la media y SD basados en 3 replicas colectadas en 4 sitios, total $\mathrm{n}=12$ ), en el arroyo Cañada del Dragón.

\begin{tabular}{|c|c|c|c|c|c|c|c|}
\hline \multirow[t]{2}{*}{ Sampling Date } & \multirow[t]{2}{*}{$n$} & \multicolumn{2}{|c|}{ Alk (mg $\left.\mathrm{CaCo}_{3} 1^{-1}\right)$} & \multicolumn{2}{|c|}{$\operatorname{STS}\left(\mathrm{mg} \mathrm{l}^{-1}\right)$} & \multicolumn{2}{|c|}{$\operatorname{SOM}\left(\mathrm{mg} \mathrm{l}^{-1}\right)$} \\
\hline & & mean & $\mathrm{SD}$ & mean & $\mathrm{SD}$ & mean & SD \\
\hline July & 12 & 61.7 & 2.3 & 35.9 & 14.5 & 5.7 & 1.4 \\
\hline September & 12 & 182.1 & 50.5 & 12.7 & 7.7 & 5.4 & 2.5 \\
\hline November & 12 & 174.5 & 46.9 & 21.7 & 8.5 & 3.7 & 1.2 \\
\hline February & 12 & 138.4 & 34.9 & 15.7 & 5.4 & 2.7 & 1.6 \\
\hline April & 12 & 151.6 & 36.4 & 27.2 & 12.7 & 3.3 & 1.4 \\
\hline June & 12 & 118.6 & 54.75 & 16.4 & 11.4 & 3.7 & 3.6 \\
\hline
\end{tabular}

2) Non-parasitized fishes:

$\log W_{T}=\log -1.44( \pm 0.04)+2.84( \pm 0.06) \log S_{L}$

Standard errors are shown in parenthesis. The allometric coefficient values did not differ significantly between the fish groups (Student test, $p<0.05$ ).

\section{DISCUSSION}

From a total of twenty-seven species, only two, $A$. aff. fasciatus and $O$. jenynsii, were infected with digenic trematodes, which could indicate a high specificity for the secondary host (de Kinkelin et al., 1985) and/or ecological characteristics of these fish that make them more susceptible (Ondracková et al., 2002). However, other species present in Cañada del Dragón stream with ecological characteristics similar to A. aff. fasciatus, such as other small non-migratory Characiformes, ("mojarras") Cheirodon interruptus (Jenyns, 1842), Bryconamericus iheringii (Boulenger, 1887), and Hyphessobrycon luetkenii (Boulenger, 1887), did not present black spot disease. On the other hand, in other streams and creeks of the Santa Lucía River basin Arroyo Colorado, Cañada del Colorado, Cañada de las Conchillas, Arroyo Las Piedras, and Cañada del Juncal, (unpublished data), we have detected black spots in species collected in this study such as "madrecita" Cnesterodon decemmaculatus (Jenyns, 1842), "overito" Jenynsia multidentata (Jenyns, 1842) (Cyprinodontiformes), and "mojarra" B. iheringii (Characiformes). These differences can be due to the presence of different parasites in the streams sampled, or to environmental characteristics causing differential infection susceptibility in fish species. The low catches of $O$. jenynsii prevented the evaluation of the prevalence and intensity of the black spot disease. Considering that $O$. jenynsii is a common species in our freshwater ecosystems (Ringuelet et al., 1967), we believe that its susceptibility to black spot disease should be further evaluated.

The prevalence, abundance, and intensity of black spot disease in A. aff. fasciatus, did not show seasonal changes. On the contrary, Chubb (1979) found seasonal changes in prevalence and abundance, related to cercarial emergence with higher water temperatures. Nevertheless, the seasonal changes in black spot abundance and prevalence can be masked as old infections (Dönges, 1964). We found the greatest intensity of black spots in the ventral region of the fish. The differential distribution of metacercariae, may be affected by behavior and habitat of hosts (snails and fish) (Ondracková et al., 2002). In this sense, Ringuelet (1975) described the Tetragonopterides, to which A. aff. fasciatus belongs, as a group of little fish that inhabit pools and vegetated zones. However, we have often captured A. aff. fasciatus, $O$. jenynsii and different snail species (i.e. Heleobia sp. and Pomacea sp.) in riffles and nonvegetated zones in the Cañada del Dragón stream. We hypothesize that the presence of potentiallyinfected snails over bare sediment, can explain the spatial pattern of the infection on the fish: the 
parasites would be released from the bottom of the water column and reach the ventral region of the fish easier than other sections of the animals.

We found no differences in growth, between infected and non infected fish, which indicates a neutral effect of this parasite on Astyanax aff. fasciatus, at least over this variable. As it does not affect growth, it is also possible that it does not cause an effect at the population level in the $W_{T}-L_{S}$ relationship.

Our results suggest that, a high susceptibility of Astyanax aff. fasciatus to black spot disease, and/or a high specificity of the parasite occurs in the Cañada del Dragón stream. This is not reflected in several host's parameters (total and standard length and weight), which only show higher infection in the ventral part of the fish. The infected fish did not seem affected, at least concerning their growth.

Future studies will be addressed to determine whether the black spot disease detected in different fish species from the Santa Lucia River basin is caused by the same species of Digenea. This would help us to understand whether the patterns of infection in this basin are due to a speciesspecific relationship between the parasite and the host, or due to environmental characteristics related to water quality.

\section{ACKNOWLEDGEMENTS}

Authors wish to thank Alejandro D'Anatro, Esteban Charbonier, Marcelo Loureiro, and Lucía Boccardi for technical assistance during data collection. Also, we would like to thank Rodrigo Ponce de Leon, Marcelo Loureiro, Carlos Iglesias, and Mariana Meerhoff for the critical revision of the manuscript. We are also grateful to the anonymous referees which helped to improve earlier versions of this manuscript.

\section{REFERENCES}

APHA. 1995. Standard methods for the examination of water and wastewater. APHA/AWWA/WPCF. Whashington, $1268 \mathrm{pp}$.
ARNOTT, S. A., I. BARBER \& F. A. HUNTINGFORD. 2000. Parasite-associated growth enhancement in a fish-cestode system. Proceedings of the Royal Society of London Series B, 267: 657-663.

BAKER, S. C. \& F. J. BULOW. 1985. Effects of Black-Spot Disease on the Condition of Stonerollers Campostoma anomalum. American Midland Naturalist, 114: 198-199.

BALLABENI, P. 1994. Experimental differences in mortality patterns between European minnows, Phoxinus phoxinus, infected with sympatric or allopatric trematodes, Diplostomum phoxini. J. Fish Biol., 45: 257-267

BUSH, A. O., K. D. LAFFERTY, J. M. LOTZ \& A. W. SHOSTAK. 1997. Parasitology meets ecology on its own terms: Margolis et al. revisited. The Journal of Parasitology, 83: 575-583.

CHUBB, J. C. 1979. Seasonal occurrence of helminths in freshwater fishes. Part II. Trematoda. Advances in Parasitology, 17: 141-313.

De KINKELIN, P., C. MICHEL \& P. GHITTINO. 1985. Tratado de las enfermedades de los peces. Editorial ACRIBIA S. A. España, Zaragosa. 368 pp.

DNH, División recursos hídricos, 1998. Aprovechamiento de los recursos hídricos superficiales inventario nacional 1997-1998. Informe técnico, 96 pp.

DÖNGES, J. 1964. The life cycle of Posthodiplostomum cuticola (v. Nordmann 1832) Dubois 1936 (Trematoda, Diplostomatidae). Zeitschrift fur Parasitenkunde, 24: 160-248.

HARRISON, E. J. \& W. F. HADLEY. 1982. Possible effects of black-spot disease on northern pike. Trans. Am. Fish. Soc., 111: 106-109.

LOOT, G., R. POULIN, S. LEK \& J. F. GUÉGAN. 2002. The differential effects of Ligula intestinalis (L.) plerocercoids on host growth in three natural populations of roach, Rutilus rutilus (L.). Ecology of Freshwater Fish, 11: 168-177.

LUCKÝ, Z. 1970. Pathological changes with posthodiplostomosis of fish fry. Acta Veteterinaria Brunensis, [Suppl] 1: 51-66.

LYAYMAN, E. M. \& O. D. SADKOVSKAYA. 1952. The black-spot disease of carps and treatment. $T r$ Nauch Issl Inst Prud Oz Rech Ryb Khoz USSR, 8: 108-116.

MAYRAT, A. 1970. Allometrie et taxinomie. Revue de Statistique Appliquée, 18: 47-58.

MUSETH, J. 2001. Efects of Ligula intestinalis on habitat use, predation risk and catchability in European minnows. J. Fish Biol., 59: 1 070-1 080. 
OLSEN, O. W. 1974. Animal parasites, their life cycles and ecology. University Park Press, Baltimore. $562 \mathrm{pp}$.

ONDRACKOVÁ, M., P. JURAJDA \& M. GELNAR. 2002. The distribution of Posthodiplostomum cuticola metacercariae in young-of-the-year cyprinid fishes. J. Fish Biol., 60: 1 355-1 357.

RICKER, W. E. 1973. Linear regressions in fishery research. Journal of the Fisheries Research Board of Canada, 30: 409-434.

RICKER, W. E. 1975. Computation and interpretation of biological statistics of fish populations. $\mathrm{Bu}$ lletin of the Fisheries Research Board of Canada, 191: 1-382.
RINGUELET, R. A., R. H. ARAMBURU \& A. ARMONIA. 1967. Los peces argentinos de agua dulce. Comision de Investigación Científica, Buenos Aires. La Plata. 602 pp.

SINDERMANN, C. J. 1987. Effects of parasites on fish populations: practical considerations. International Journal of Parasitology, 17: 371-382.

SOKAL, R. R. \& F. J. ROHLF. 1979. Biometría: Principios y métodos estadísticos en investigación biológica. Editorial H. Blume, Madrid. 832 pp.

STRAHLER, A. N. 1986. Geografía física. Ed. Omega, S.A., Barcelona. 767 pp.

ZAR, J. H. 1999. Bioestadistical Analysis. 3th edition, New Jersey: Prentice Hall Inc. 663 pp. 